\title{
Etik Dan Profesionalisme Perawat Dan Bidan Puskesmas Marawola Kabupaten Sigi Pada Masa Tanggap Bencana Gempa Bumi
}

\author{
*Nasrun ${ }^{1}$, Fathya ${ }^{2}$ \\ ${ }^{I}$ Bioetik Sekolah Pascasarjana Universitas Gadjah Mada \\ ${ }^{2}$ Fakultas Kedokteran Universitas Jenderal Achmad Yani
}

\author{
*) Correspondence Author \\ Nasrun \\ Bioetik Sekolah Pascasarjana Universitas Gadjah Mada \\ Email: n4sroen@yahoo.com
}

\begin{abstract}
Palu city, Donggala, was hit by a 7.4 scale earthquake followed by a tsunami and liquefaction in September 2018 . Numerous casualties were reported, particularly Maralowa health centre, Sigi district. Medical personnel should strictly adhere to their competencies. However, it is not uncommon to act beyond their capacity during a natural disaster. We are interested in investigating the ethical issues and professional aspect of medical personnel during an emergency. The research was conducted from March to June 2020, with qualitative methods using in-depth interviews of 8 participants who lived in Marawola Health Center at the time of the earthquake disaster. We used the Miles and Huberman method (1992) for data analysis. Medical personnel experienced a heavy load of working burden and psychological pressure; they were even unprepared for this condition. Overlapping competency is happening among medical personnel, but we did not found any ethical issues nor professionals breach during practice in Marawola Health Center.
\end{abstract}

Key Word: Nurses, Midwives, Professionalism, Disasters.

\begin{abstract}
Abstrak
28 September 2018 jam 18.02 WITA kota Palu dan kota-kota sekitarnya, Sigi, Donggala yang dilalui oleh patahan Palu-Koro mengalami bencana gempa bumi 7,4 skala richter yang kemudian disusul tsunami dan likuifaksi, sehingga membawa korban yang cukup besar, seperti wilayah kerja PUSKESMAS Marawola kabupaten Sigi yang pada saat kejadian bencana tenaga medis sama sekali tidak dipersiapkan dalam situasi tersebut. Tenaga medis dituntut untuk tetap bertindak sesuai kompetensi mereka, untuk itu peneliti tertarik untuk meneliti peran penting Etik dan Profesionalisme pada situasi bencana. Penelitian dilaksanakan dari Maret hingga Juni 2020, dengan metode kualitatif menggunakan wawancara mendalam hingga didapatkan data jenuh dengan sampel 8 orang subyek informan yang berada di PUSKESMAS Marawola pada saat kejadian bencana gempa bumi. Data di olah dan dianalisa menggunakan metode Miles dan Huberman (1992) yang mana aktivitas dalam analisis data dilakukan secara interaktif dan terus-menerus hingga akhirnya pada tahap data reduction, data display, dan conclusion. Tentunya akan menjadi dilema bila bekerja dalam kondisi pasca bencana yang tidak dapat diduga akan terjadi, mulai dari pasien perawatan sebelum gempa dan korban gempa yang berdatangan, tindakan medis oleh perawat dan bidan pada korban bencana gempa bumi, kurangnya kesiapsiagaan mitigasi bencana pada PUSKESMAS Marawola, hingga bekerja dalam kondisi penuh tekanan dari beberapa korban gempa beserta keluarga. Namun itu semua tidak menjadi halangan untuk menolong korban bencana berdasarkan indikasi medis, sehingga telah sesuai berdasarkan etika dan profesionalisme mereka sebagai tenaga medis di PUSKESMAS Marawola.
\end{abstract}

Kata Kunci : Perawat, Bidan, Profesionalisme, Bencana. 


\section{PENDAHULUAN}

Bencana gempa, tsunami dan likuifaksi yang menimpa kota Palu, Sigi dan Donggala pada tanggal 28 September 2018 pukul 18.02 WITA dengan kekuatan 7,4 skala richter menyebabkan banyak korban yang berjatuhan, baik korban jiwa atau luka-luka. Masyarakat yang bermukim di wilayah kecamatan Marwola kabupaten Sigi, mereka yang menjadi korban mencari pertolongan ke PUSKESMAS Marawola, meski dengan keterbatasan yang ada pada sarana dan fasilitas PUSKESMAS.

Profesionalisme merupakan kompetensi yang terdiri atas etitude, keterampilan, dan pengetahuan yang diperoleh dari strategi pembelajaran dan pelatihan yang diselenggarakan oleh suatu perkumpulan atau institusi, Sastrowijoto $(2014)^{16}$. Adapun etik profesi perawat berdasarkan PPNI (2015) ${ }^{12}$ dan bidan yang tertuang pada Kode Etik Bidan (1988). Tentunya didalam menjalankan profesi mereka sebagai tenaga kesehatan tidak lepas dari perilaku yang profesional dan beretika, seperti perawat dan bidan yang masih tetap tinggal tanpa pamrih memberikan pertolongan dalam keadaan yang serba terbatas, meski sebelumnya harus memprioritaskan pasien yang masih dalam perawatan.

Adapun korban gempa yang terdiri dari berbagai macam luka atau trauma berdatangan untuk meminta pertolongan yang tentuanya akan menjadi dilema bagi tenaga medis dikarenakan tidak adanya dokter yang berdinas, adanya beberapa luka atau trauma yang bukan kompetensi mereka dan tentunya memikirkan bagaimana nasib keluarga dirumah. Sehingga peneliti tertarik untuk menggali dari aspek etik dan profesonalisme alasan mereka untuk tidak meninggalkan tugasnya demi menolong korban yang datang meminta pertolongan tindakan medis

\section{METODE DAN SAMPEL}

Setelah peneliti mendapatkan persetujuan etik penelitian dari Komisi Etik Penelitian Kesehatan Fakultas Kedokteran UNISA Palu, penelitian kemudian dilaksanakan dengan metode kualitatif dengan pendekatan studi kasus melalui wawancara mendalam dari bulan Maret hingga Juni 2020 kepada tenaga medis perawat dan bidan yang bertugas pada PUSKESMAS Marawola. Kemudian dilanjutkan triangulasi kepada tenaga non-medis dan, setelah data cukup diolah dengan metode analisa Miles dan Huberman (1992). Adapun kriteria sampel yang dipilih yaitu sejumlah 8 informan yang terdiri dari tenaga medis perawat 2 orang dengan masa kerja masingmasing 8 dan 2 tahun, bidan 4 orang dengan masa kerja 3 hingga 4 tahun serta triangulasi wawancara kepada tenaga non medis 1 orang sopir ambulance dengan masa kerja 1 tahun 6 bulan dan, Bagian Sumber Daya Manusia Dinas Kesehatan Kabupaten Sigi yang 
membawahi wilayah kerja PUSKEMAS Marawola

sejumlah 1 orang dengan masa kerja 11 tahun.

Diharapkan peneliti mendapatkan informasi data

wawancara yang dapat memberikan pengalaman

senyatanya dari informan yang mengalami kejadian

pada saat dan sesaat setelah bencana, guna menangkap

makna pada aspek etik dan profesionalisme informan

dan untuk pengambilan keputusan dalam kondisi

dilema pada saat triase, tindakan medis pada kondisi

pre hospital hingga rujukan ke rumah sakit terdekat.

\section{Hasil Penelitian}

Terdapat 4 sub tema etik dan profesionalisme pada studi kasus penelitian ini, yaitu :

Tabel 1.Pasien dalam perawatan sebelum gempa dan korban gempa.

\begin{tabular}{|c|c|c|}
\hline Kategori & Sub Kategori & $\overline{\mathrm{Te} \mathrm{m} \mathrm{a}}$ \\
\hline $\begin{array}{l}\text { Pasien } \\
\text { PUSKESMAS } \\
\text { Bukan akibat } \\
\text { gempa }\end{array}$ & $\begin{array}{l}\text { Beberapa pasien } \\
\text { yang masih } \\
\text { dalam perawatan } \\
\text { di PUSKESMAS } \\
\text { Marawola sesaat } \\
\text { sebelum gempa }\end{array}$ & $\begin{array}{l}\text { Pasien } \\
\text { perawatan } \\
\text { sebelum } \\
\text { gempa dan } \\
\text { korban gempa } \\
\text { yang }\end{array}$ \\
\hline $\begin{array}{l}\text { Macam-macam } \\
\text { luka atau trauma } \\
\text { korban hidup } \\
\text { akibat gempa }\end{array}$ & $\begin{array}{l}\text { Beberapa jenis } \\
\text { luka serta } \\
\text { komplikasi } \\
\text { akibat trauma } \\
\text { bencana gempa } \\
\text { yang diluar } \\
\text { kompetensi }\end{array}$ & berdatangan \\
\hline $\begin{array}{l}\text { Korban } \\
\text { meninggal } \\
\text { sempat dirawat } \\
\text { dan dibawa oleh } \\
\text { keluarga korban }\end{array}$ & $\begin{array}{l}\text { Korban } \\
\text { meninggal dan } \\
\text { yang masih } \\
\text { hidup }\end{array}$ & \\
\hline $\begin{array}{l}\text { Jumlah korban } \\
\text { akibat gempa } \\
\text { yang datang ke } \\
\text { PUSKESMAS } \\
\text { Marawola }\end{array}$ & & \\
\hline
\end{tabular}

1) Pasien perawatan sebelum gempa dan korban gempa yang berdatangan dengan sub kategori :

a. Pasien yang masih dalam perawatan di PUSKESMAS Marawola sesaat sebelum terjadinya bencana gempa. Pada bagian kebidanan terdapat seorang pasien post partum dengan bayinya dan pasien emesis, pada perawatan umum terdapat 2 orang pasien dengan diagnosa gastritis dan seorang pasien suspek HIV Aids, sehingga total pasien sesaat sebelum kejadian bencana gempa berlangsung berjumlah 6 orang.

b. Beberapa jenis luka serta komplikasi diluar kompetensi. Berbagai macam jenis luka yang diderita oleh korban gempa yang berdatangan ke PUSKESMS Marawola diluar kompetensi mereka sebagai tenaga medis perawat dan bidan, seperti pendarahan bagian dalam, robekan di kepala, mata yang tertusuk paku, tangan yang patah tulang dan hanya dilapisi oleh kulit, hingga korban likuifaksi (lumpur).

c. Korban meninggal dan yang masih hidup. Total korban yang berdatangan di PUSKESMAS Marawola akibat bencana gempa baik korban jiwa maupun yang masih hidup sekitar 50 orang. Beberapa korban yang sempat ditangani tidak dapat bertahan lama hingga akhirnya setelah dirawat sehari malam berikutnya meninggal, dan beberapa korban gempa yang datang dalam kondisi tidak dapat tertolong nyawanya. 
Tabel 2. Tindakan medis oleh Perawat dan Bidan.

\begin{tabular}{|c|c|c|}
\hline Kategori & Sub Kategori & T e m a \\
\hline $\begin{array}{l}\text { Pemeriksaan } \\
\text { tanda vital serta } \\
\text { perawatan luka } \\
\text { pada korba } \\
\text { bencana gempa }\end{array}$ & $\begin{array}{l}\text { Tindakan medis } \\
\text { sementara pada } \\
\text { korban bencana } \\
\text { gempa }\end{array}$ & \multirow{2}{*}{$\begin{array}{l}\text { Tindakan } \\
\text { medis oleh } \\
\text { perawat dan } \\
\text { bidan pada } \\
\text { korban } \\
\text { bencana } \\
\text { gempa bumi }\end{array}$} \\
\hline $\begin{array}{l}\text { Tindakan medis } \\
\text { serta pemberian } \\
\text { terapi obat-obatan } \\
\text { diluar kompetensi } \\
\text { perawat dan bidan }\end{array}$ & $\begin{array}{l}\text { Beberapa } \\
\text { tindakan medis } \\
\text { diluar } \\
\text { kompetensi } \\
\text { perawat dan } \\
\text { bidan }\end{array}$ & \\
\hline
\end{tabular}

2) Tindakan medis oleh perawat dan bidan pada korban bencana gempa bumi dengan sub kategori:

a. Tindakan medis sementara pada korban bencana gempa. Keterbatasan obat-obatan dan peralatan medis yang sebagian tidak dapat digunakan lagi tidak menjadikan halangan bagi tenaga medis perawat dan bidan untuk memberikan pertolongan. Tindakan awal dengan pemeriksaan tanda vital, pemeriksaan luka, hingga rawat luka, semua dilakukan sesuai dengan batas kemampuan mereka, seperti pada kutipan wawancara berikut ini "Sudah kita lakukan pertolongan seperti bagaimana seharusnya". Adapun untuk beberapa luka seperti trauma kepala mereka hanya melakukan tindakan pergantian verban yang intinya agar luka tertutup.

b. Beberapa tindakan medis diluar kompetensi perawat dan bidan. Adanya beberapa jenis luka yang diluar kompetensi mereka sebagai tenaga medis perawat dan bidan, nanun mereka tetap memberikan pertolongan pertama berupa menjahit luka termasuk pada luka dalam, pemberian obat penurun demam dan antibiotik akibat komplikasi infeksi, hingga pemberian cairan intravena untuk mencegah dehidrasi dan syok hipovolemik pada pendarahan aktif yang diakibatkan oleh luka terbuka.

Tabel 3. Kurangnya kesiapsiagaan mitigasi bencana.

\begin{tabular}{|c|c|c|}
\hline Kategori & Sub Kategori & T e m a \\
\hline $\begin{array}{l}\text { Belum pernah } \\
\text { mengikuti } \\
\text { pelatihan } \\
\text { mitigasi bencana }\end{array}$ & $\begin{array}{l}\text { Belum adanya } \\
\text { pengetahuan } \\
\text { perawat dan } \\
\text { bidan terhadap } \\
\text { mitigasi } \\
\text { bencana }\end{array}$ & $\begin{array}{l}\text { Kurangnya } \\
\text { kesiapsiagaan } \\
\text { mitigasi } \\
\text { bencana pada } \\
\text { PUSKESMAS } \\
\text { Marawola serta }\end{array}$ \\
\hline $\begin{array}{l}\text { Beberapa jenis } \\
\text { pelatihan diluar } \\
\text { mitigasi bencana }\end{array}$ & $\begin{array}{l}\text { Belum adanya } \\
\text { pengetahuan } \\
\text { perawat dan } \\
\text { bidan terhadap } \\
\text { mitigasi } \\
\text { bencana }\end{array}$ & Kabupaten Sigi \\
\hline $\begin{array}{l}\text { Mitigasi bencana } \\
\text { pada PEMDA } \\
\text { Kab. Sigi }\end{array}$ & \multirow{2}{*}{$\begin{array}{l}\text { Mitigasi } \\
\text { bencana yang } \\
\text { tidak disertai } \\
\text { dengan regulasi } \\
\text { dari Pemda } \\
\text { Kabupaten Sigi }\end{array}$} & \\
\hline $\begin{array}{l}\text { PERDA } \\
\text { Kebencanaan } \\
\text { yang belum ada } \\
\text { pada Kabupaten } \\
\text { Sigi sebelum } \\
\text { bencana gempa } \\
\text { bumi }\end{array}$ & & \\
\hline
\end{tabular}

3) Kurangnya kesiapsiagaan mitigasi bencana pada PUSKESMAS Marawola serta Kabupaten Sigi. Dengan sub kategori :

a. Belum adanya pengetahuan perawat dan bidan terhadap mitigasi bencana. Tenaga kesehatan termasuk tenaga medis perawat dan bidan di PUSKESMAS Marawola sebelum kejadian gempa bumi, sama sekali belum pernah mendapatkan pelatihan tentang mitigasi atau tanggap bencana, hal tersebut di pertegas pada kutipan wawancara perawat yang bertugas selama 
8 tahun di PUSKESMAS Marawola, "Sa..tidak pernah mengikuti pelatihan tanggap bencana belum pernah.". Begitupun hasil kutipan wawancara bidan yang saat bencana gempa berlangsung sedang bertugas di PUSKESMAS Marawola, mengatakan bahwa "iya pas kuliahnya saja..kalau kerja belum pernah..", dan kutipan berikut "Bukan tentang bencana lebih ke RJP”.

b. Mitigasi bencana yang tidak disertai dengan regulasi dari Pemerintah Daerah KabupatenSigi.

Pemerintah Kabupaten Sigi telah mempunyai prosedur mitigasi bencana, hal ini di pertegas pada saat wawancara triangulasi kepada informan dari Dinas Kesehatan Kabupaten Sigi yang mengatakan bahwa "mitigasi pemerintah daerah memang ada serta tim seksinya tetapi tidak jalan karena belum pernah mengalami bencana gempa", yang artinya tim mitigasi bencana alam hanya ada pada Dinas Kesehatan Kabupaten Sigi. Meskipun telah ada prosedur mitigasi bencana di Pemerintah Daerah Kabupaten Sigi beserta timnya, namun tidak disertai dengan regulasi atau aturan pendukung pelaksanaannya dilapangan untuk tanggap menjalankan prosedur mitigasi tersebut, seperti yang disampaikan melalui kutipan wawancara berikut ini "Regulasi juga belum ada belum ada waktu itu", sehingga semuanya itu tidak dapat berjalan dengan maksimal.
Tabel 4. Bekerja dalam kondisi penuh tekanan

\begin{tabular}{|c|c|c|}
\hline Kategori & Sub Kategori & $\mathrm{Te} \mathrm{m} \mathrm{a}$ \\
\hline $\begin{array}{l}\text { Ekspresi } \\
\text { kekecewaan tidak } \\
\text { menerima } \\
\text { keputusann tenaga } \\
\text { medis }\end{array}$ & $\begin{array}{l}\text { Intimidasi dari } \\
\text { warga dan } \\
\text { korban gempa }\end{array}$ & $\begin{array}{l}\text { Bekerja } \\
\text { dalam } \\
\text { kondisi } \\
\text { penuh } \\
\text { tekanan dari }\end{array}$ \\
\hline $\begin{array}{l}\text { Beberapa reaksi } \\
\text { emosi korban serta } \\
\text { warga kepada } \\
\text { tenaga medis }\end{array}$ & & $\begin{array}{l}\text { beberapa } \\
\text { korban } \\
\text { gempa } \\
\text { beserta } \\
\text { keluarga. }\end{array}$ \\
\hline
\end{tabular}

4 Bekerja dalam kondisi penuh tekanan dari beberapa korban gempa beserta keluarga. Dengan sub kategori intimidasi dari warga dan korban gempa. Tekanan atau Intimidasi yang dialami oleh tenaga medis bidan dan perawat terdiri dari beberapa ancaman oleh masyarakat setempat yang datang meminta pertolongan ke PUSKESMAS. Sesaat setelah gempa bumi berlangsung ada bebarapa pasien yang akan dirujuk ke rumah sakit namun terhalang oleh sopir ambulance yang belum berada di PUSKESMAS Marawola sesaat setelah gempa dikarenakan masih berada dirumah sehingga warga berinisiatif untuk menghancurkan ambulance tersebut bila tidak dapat digunakan untuk merujuk. Reaksi emosi lain yang dialami oleh tenaga medis perawat dan bidan adalah adanya beberapa korban gempa bumi yang datang tidak dapat ditindak lanjuti langsung pada saat itu juga, seperti kutipan wawancara dari ucapan keluarga korban yang ditirukan "itukan sudah tugas kamu sebagai seorang medis", fasilitas yang terbatas dikarenakan persediaan peralatan 
medis dan obat-obatan yang menipis. Karena alasan tersebut setelah beberapa hari berjalan tenaga medis bidan dan perawat tersebut, setelah beberapa hari berjalan, tenaga medis bidan dan perawat berencana untuk menutup PUSKESMAS Marawola, namun pada akhirnya rencana tersebut diketahui oleh warga yang datang sehingga ada beberapa warga setempat yang mengancam akan membakar PUSKESMAS Marawola bila ditutup

\section{PEMBAHASAN}

Tidak mudah untuk memutuskan korban mana yang harus ditolong, sehingga menjadi tantangan tersendiri dalam situasi yang sulit dan serba terbatas, ditambah dengan situasi dimana beberapa korban dan keluarganya yang tidak menerima dan mengintimidasi mereka jika PUSKESMAS Marawola ditutup, hingga akhinya diputuskan untuk tidak jadi ditutup dan tetap memberikan pelayanan dalam kondisi fasilitas yang sangat terbatas. Meskipun korban datang dengan beberapa luka atau trauma yang diluar kewenangan kompetensi profesi tenaga medis perawat dan bidan, mereka tetap memberikan tindakan medis sebatas pertolongan pertama sebelum dirujuk (pre hospital). Tindakan yang diambil pada saat itu yaitu berupa memilah korban (triase), lalu memberikan pertolongan secepatnya (respon time) sesuai dengan indikasi yang ada.
Pada Kerangka Kompetensi International Council Of Nurses (ICN, 2009) ${ }^{6}$. Kompetensi Perawatan Dalam Pencegahan / Mitigasi (prevention / Mitigation) terbagi didalam penyediaan bagi individu dan keluarga yang terdiri atas poin b yaitu (1) Melakukan triage bencana; (2) Melakukan tindakan penatalaksanaan trauma; (3) Melakukan tindakan untuk memenuhi kebutuhan klien akibat bencana; Menciptakan lingkungan yang aman untuk masyarakat dan klien; (5) Melakukan rujukan yang aman.

Pada kebidanan telah tertuang di Pedoman Lapangan Antar-Lembaga Kesehatan Reproduksi Dalam Situasi Darurat Bencana, dijelaskan pada tujuan Paket Pelayanan Awal Minimum (PPAM), untuk pencegahan meningkatnya kesakitan dan kematian maternal dan neonatal dengaan memastikan tersedianya layanan kegawatdaruratan kebidanan $($ EmOC $=$ emergency obstetric care) dan layanan perawatan bayi baru lahir.

Prosedur yang mereka laksanakan sesuai dengan Training Manual Ethics in Epidemics, Emergencies and Disasters: Research, surveillance and patient care. Badan kesehatan dunia WHO (2015). Yang menyatakan bahwa "Selama keadaan darurat, salah satu tujuan utama dari personil medis dan kesehatan masyarakat adalah untuk meminimalkan kematian dan morbiditas". Pada situasi keterbatasan waktu dan sumber daya, dengan kemampuan mereka untuk tindakan medis terbatas, dengan respon time yang 
dimiliki, mereka harus mampu melakukan pemilahan

(triase) siapa yang harus diberikan perawatan.

Kode Etik Perawat (PPNI,2015) $)^{12}$ huruf B.

Perawat dan Praktik pada ayat (2) yaitu :

"Perawat senantiasa memelihara mutu pelayanan

keperawatan yang tinggi disertai kejujuran profesional

yang menerapkan pengetahuan serta keterampilan

keperawatan sesuai dengan kebutuhan klien “

sehingga dapat kita artikan meskipun dalam suasana

serba terbatas dengan kondisi yang darurat dan

dibawah intimidasi, mereka tetap melakukan tindakan

secara profesional dengan penuh kehati-hatian, sesuai

dengan ungkapan (local wisdom) masyarakat suku

Kaili Sulawesi Tengah yaitu nasehat bekerja secara

hati-hati "Dopa nisama jara nagovamo" artinya

belum dikekang kudanya sudah berlari, maksudnya

ungkapan bagi seseorang yang bertindak melakukan sesuatu pekerjaan atau keputusan yang terlalu cepat atau tergesa-gesa, tanpa memikirkan akibatnya atau tanpa persiapan yang mengakibatkan perbuatan itu fatal suatu kerugian yang tidak terhindarkan,Sukmawati $(2013)^{21}$.

Pasien kebidanan pada saat situasi bencana masih tetap dalam penanganan atau dan setelah bayi lahir mereka segera di evakuasi. Tindakan tersebut sesuai dengan Kode Etik Bidan (1988) yang tertuang pada Kewajiban Bidan Terhadap Pasien dan Masyarakat, pada pasal (4)
"Setiap bidan dalam menjalankan tugas senantiasa mendahulukan kepentingan pasien, menghormati hak hak pasien serta dan nilai - nilai yang dianut oleh pasien"

Pada prinsip Kaidah Dasar Bioetik Childres JF dan Beauchamp T (1979) dijabarkan sebagai berikut :

1) Beneficence (kebaikan) Prinsip ini mengutamakan tindakan yang memberi kebaikan kepada pasien atau yang manfaatnya jauh lebih besar dari pada mudaratnya atau kerugiannya. Tenaga medis pada PUSKESMAS Marawola telah memanfaatkan segala cara yang digunakan untuk menolong korban bencana, dengan mengevakuasi semua pasien dalam masa perawatan dititik kumpul PUSKESMAS hingga menolong korban bencana yang berdatangan, memberikan obat-obatan sesuai indikasi medis, rawat luka akibat cedera yang diderita, merujuk pasien yang membutuhkan tindakan lebih lanjut dirumah sakit.

2) Non-Maleficence, berasal dari dua kata: male $($ jahat $)+$ fic (berbuat) prinsip ini sangat jelas melarang tindakan yang membahayakan atau memperburuk keadaan pasien. Meskipun dibatasi oleh kompetensi mereka sebagai tenaga medis perawat dan bidan, mereka bertindak sesuai dengan kompetensi yang dimiliki untuk menolong korban yang berdatangan. Adapun beberapa luka atau trauma yang diderita korban gempa diluar kompetensi mereka, tetap prosedur rujukan 
dilaksanakan setelah pasien mendapatkan tindakan medis sementara (pre hospital) .

3) Autonomy (Otonomi) yang berasal dari bahasa Yunani yang terdiri atas dua suku kata yaitu "autos" yang berarti sendiri dan "nomos" yang berarti peraturan. Prinsip ini menghormati hakhak pasien, terutama hak otonomi pasien (the rights to self determination) hak untuk menentukan nasibnya sendiri. Beberapa hari setelah kejadian gempa bumi, PUSKESMAS Marawola kekurangan peralatan medis serta obatobatan, tentunya akan menjadi dilema dalam memberikan pelayanan medis kepada korban gempa, sehingga niat untuk menghentikan pelayanan operasional di PUSKESMAS Marawola beberapa saat menjadi pilihan oleh tenaga medis yang masih bertugas. Pada posisi mereka sebagai tenaga kesehatan serta sekaligus sebagai korban dari bencana gempa bumi yang melanda tentunya mereka mempunyai hak untuk memperoleh perlindungan terhadap diri mereka masing-masing, baik dari segi keamanan dalam menjalankan tugas dikarenakan adanya beberapa intimidasi yang diterima hingga kesehatan mereka selama menolong korban bencana. Akan tetapi hak otonomi yang dimiliki oleh mereka sebagai tenaga kesehatan masih dapat dikesampingkan demi profesionalisme mereka untuk tetap menghargai hak otonomi yang dimilki oleh pasien atau korban bencana gempa bumi untuk mendapatkan tindakan medis dan obat-obatan.

4) Justice. Prinsip moral yang mementingkan fairness dan keadilan dalam bersikap maupun dalam mendistribusikan sumber daya (distributive justice) atau pendistribusian dari keuntungan, biaya dan risiko secara adil serta berdasarkan kondisi medis. Dengan penanganan awal memilah (traise) pasien dengan indikasi atas kondisi medis yang dimilki korban, selanjutnya memprioritaskan pasien mana saja yang harus terlebih dahulu dirujuk mengingat waktu (respon time) sangat penting bagi korban yang dalam kondisi kritis untuk mendapatkan pertolongan lebih lanjut dirumah sakit.

Prinsip Etika Medis Jonsen and Siegler (2002) $)^{7}$ dapat kita lihat pada situasi bencana di PUSKESMAS Marawola sebagai berikut :

1) Medical indication adalah fakta, opini, dan penafsiran mengenai kondisi fisik dan atau psikologis pasien yang memberikan dasar yang masuk akal untuk mendiagnosis hingga memberikan tindakan medis dan terapi. Sesuai dengan kompetensi yang miliki sebagai perawat dan bidan tentunya bukan menjadi kewajiban mereka untuk menentukan diagnosa pasti dari apa yang diderita oleh korban, akan tetapi dalam langkah awal penanganan korban, prosedur tindakan medis yang diberikan mereka harus 
mempunyai dasar indikasi medis untuk diagnosa sementara sehingga dapat melaksanakan pertolongan lebih lanjut.

2) Patient Preferrences, yang dapat dilihat adalah nilai (value) terhadap pemahaman yang ada pada pasien serta penilaian tentang manfaat dan beban atas keputusan yang akan diterimanya terhadap tindakan medis yang akan diambil. Pada kondisi segala sesuatu serba darurat, tergantung pada penilaian kondisi korban dari yang luka ringan hingga luka berat, kemudian beberapa tindakan medis membutuhkan penanganan awal dengan segera tidak lagi atau tanpa persetujuan tindakan medis (informed consent) dari korban atau keluarga korban, namun tetap komunikasi efektif antara tenaga medis dengan korban, atau keluarga korban terlebih dahulu dikedepankan.

3) Quality of Life memandang tujuan dari pengobatan atas tindakan medis yang akan diambil maupun yang telah dilakukan. Tentunya semua tindakan medis yang telah dilakukan oleh perawat dan bidan di PUSKESMAS Marawola semua mempunyai tujuan akhir yaitu demi kesembuhan atau keselamatan para korban yang berdatangan meminta pertolongan.

4) Contextual Features merupakan penilaian diluar dari aspek medis ( faktor non medis) yang dapat mempengaharui keputusan atau tindakan medis yang diambil, baik dari sudut pandang pasien maupun tenaga medis. Pada tenaga kesehatan di PUSKESMAS Marawola tentunya jaminan keselamatan diri mereka dalam menjalankan kewajiban menolong korban bencana gempa sangat perlu dan harus diutamakan, hal ini dikarenakan bila tidak adanya perlindungan atas keselamatan diri mereka dalam menjalankan tugas,akan berdampak atau mempengaharui kualitas tindakan medis, ehingga hasil akhirnya sebaliknya akan memperburuk keadaan korban bencana di PUSKESMAS Marawola.

Aspek hukum kebencanaan di Indonesia sendiri telah banyak regulasi yang mengatur, pasal 28 ayat 1 Undang - undang Dasar Negara Republik Indonesia tahun 1945 dengan jelas menyatakan bahwa "Setiap orang berhak hidup sejahtera lahir dan batin, bertempat tinggal, dan mendapatkan lingkungan hidup yang baik dan sehat serta berhak memperoleh pelayanan kesehatan". Kemudian Kitab Undang undang Hukum Pidana pasal 304 menyatakan bahwa "Barang siapa dengan sengaja menyebabkan atau membiarkan orang dalam kesengsaraan, sedang ia wajib memberi kehidupan, perawatan atau pemeliharaan pada orang itu karena hukum yang berlaku atasnya atau karena menurut perjanjian, dihukum penjara selama-lamanya dua tahun delapan bulan, atau denda sebanyak-banyaknya Rp.4.500" 23 
Pejelasan pasal tersebut dengan tegas dalam kutipannya yang berbunyi " wajib memberi kehidupan, perawatan atau pemeliharaan pada orang itu karena hukum yang berlaku atasnya" merupakan penegasan bagi tenaga medis perawat dan bidan yang telah mengikuti jenjang pendidikan profesi kesehatan dan telah lulus uji kompetensi tenaga kesehatan yang di buktikan dengan Surat Tanda Registrasi (STR) yang telah diakui oleh negara, maka wajiblah atas mereka untuk memberikan pertolongan kepada korban gempa.

Pada prinsip kerentanan (Vulnerability) oleh PBB (2001) memberikan defenisi sebagai berikut :

"Vulnerability (kerentanan) adalah keadaan yang terpapar secara tinggi kepada risiko tertentu, yang dikombinasikan dengan berkurangnya kemampuan untuk melindungi atau mempertahankan diri melawan risiko tersebut dan juga melawan konsekuensi negatifnya"

Dari definisi tersebut, yang menjadikan vulnerable adalah keterpaparan yang tinggi pada risiko tertentu dan ketidak mampuan diri untuk mengatasinya sehingga memerlukan pihak lain untuk mengatasinya, Kusmaryanto $(2016)^{10}$. Pada kata “ketidak mampuan diri" memberikan ruang kepada tenaga perawat dan bidan untuk segera mengambil tindakan medis dan pengobatan tanpa menunggu lagi adanya persetujuan tindakan medis, akan tetapi prosedur serta maksud dan tujuan tindakan tersebut harus terlebih dahulu dijelaskan bagi korban maupun keluarga korban.
Penjelasan pada pasal 45 ayat (1) Undang undang Nomor .29 Tahun 2004 Tentang Praktik Kedokteran yaitu :

1. Dalam keadaan gawat darurat, untuk menyelamatkan jiwa pasien tidak diperlukan persetujuan. Namun, setelah pasien sadar atau dalam kondisi yang sudah memungkinkan, segera diberikan penjelasan dan dibuat persetujuan.

2. Dalam hal pasien adalah anak-anak atau orang yang tidak sadar, maka penjelasan diberikan kepada keluarganya atau yang mengantar. Apabila tidak ada yang mengantar dan tidak ada keluarganya sedangkan tindakan medis harus dilakukan maka penjelasan diberikan kepada anak yang bersangkutan atau pada kesempatan pertama pasien sudah sadar.

Kewenangan dalam memberikan pertolongan tindakan medis kepada korban tentunya tidak dapat diberikan secara mandatoris atau pendelegasian secara langsung dan tertulis dari dokter yang bertugas di PUSKESMAS Marawola, berhubung pada saat kejadian dokter tidak berada ditempat sesaat sebelum dan sesudah kejadian gempa bumi berlangsung, hal tersebut tentunya membawa dampak pertimbangan atas keputusan tindakan serta pengobatan yang akan diambil dengan segera oleh para tenaga medis yang saat itu bertugas. Pada Undang-Undang Republik Indonesia Nomor 30 Tahun 2014 Tentang Administrasi 
Pemerintahan Bagian Keempat Atribusi, Delegasi, dan

Mandat. Pada pasal 11 yang berbunyi : "Kewenangan

diperoleh melalui Atribusi, Delegasi, dan/atau

Mandat", lalu pasal 12 yaitu Atribusi yang terdiri dari

ayat : (1) Badan dan/atau Pejabat Pemerintahan memperoleh Wewenang melalui Atribusi apabila: (a) diatur dalam Undang-Undang Dasar Negara Republik Indonesia Tahun 1945 dan/atau undang-undang; (b) Merupakan wewenang baru atau sebelumnya tidak ada; dan (c) Atribusi diberikan kepada Badan dan/atau Pejabat Pemerintahan; (2) Badan dan/atau Pejabat Pemerintahan yang memperoleh Wewenang melalui Atribusi, tanggung jawab; (3) Kewenangan berada pada Badan dan/atau Pejabat Pemerintahan yang bersangkutan. Kewenangan Atribusi tidak dapat didelegasikan, kecuali diatur di dalam Undang-Undang Dasar Negara Republik Indonesia Tahun 1945 dan/atau undang-undang.

Atas peraturan tersebut terdapat dasar hukum, kewenangan yang diperoleh tenaga perawat dan bidan di PUSKESMAS Marawola untuk memberikan pertolongannya yang sesuai dengan standar profesi yang dimiliki serta peraturan perundang-undangan berikut :

(1) Undang-Undang Republik Indonesia Nomor.36

Tahun 2009 Tentang Kesehatan, pada pasal 82, 83, dan pasal $85 ;^{23}$
(2) Undang-Undang Republik Indonesia Nomor 36 Tahun 2014 Tentang Tenaga Kesehatan, pasal 59 dan pasal $63 ;{ }^{26}$

(3) Peraturan Menteri Kesehatan Republik Indonesia Nomor 26 Tahun 2019 Tentang Peraturan Pelaksanaan Undang-Undang Nomor 38 Tahun 2014 Tentang Keperawatan. Bagian Kedua Tugas dan Wewenang pada pasal 16, dan pasal 30, kemudian bagian Ketiga yaitu Keadaan Darurat pasal 33, lebih lanjut bagian Kelima tentang Hak dan Kewajiban pada pasal 35 ;

(4) Undang-Undang Republik Indonesia Nomor 4 Tahun 2019 Tentang Kebidanan. Kewenangan bila berada dalam kondisi tertentu dimana tidak terdapat tenaga kesehatan lainnya, seperti yang tertuang pada pasal 46, lalu dipertegas pada pasal 56, adapun pada kondisi gawat darurat tertuang pada pasal $59 ;{ }^{28}$

(5) Peraturan Pemerintah Nomor 21 Tahun 2008 Tentang Penyelenggaraan Penanggulangan Bencana. Peran serta tenaga kesehatan dalam mitigasi bencana tertuang pada perlindungan terhadap kelompok rentan, yang terdiri dari pasal 21 dan pasal 53;

(6) Peraturan Daerah Kabupaten Sigi Nomor 2 Tahun 2012 Tentang Penanggulangan Bencana Alam, pada Bab VII Penyelenggaraan Penanggulangan Bencana yang terdiri dari pasal 
17 dan pasal 29.

Sejalan dengan hasil penelitian yang dilakukan oleh Fatemeh, dkk $(2012)^{4}$ yang mendapatkan hasil pada sub tema etika profesionalisme, dapat dikatakan bahwa mereka tenaga perawat, dengan kondisi apapun dalam situasi bencana harus mempertahankan atau fokus pada tanggung jawab professional dan pentingnya bertindak secara etis dalam menolong korban harus sesuai dengan pedoman atau regulasi tentang aturan hukum pada pelayanan kesehatan khususnya pada situasi bencana terhadap segala macam perubahan yang terjadi pada pasien. Setelah regulasi yang mengatur tetang aspek mitigasi bencana, juga sangat penting untuk diberikannya pelatihan kepada para tenaga kesehatan baik medis maupun non medis untuk meningkatkan kesiap-siagaan mengahadapi situasi bencana, seperti hasil penelitian yang dilakukan oleh Novria, dkk $(2018)^{11}$ yang memperlihatkan hasil pelatihan merupakan faktor dominan terhadap kesiapsiagaan bidan dalam menghadapi bencana. Dengan demikian sangat jelas diuraikan bahwa aturanaturan tentang mitigas bencana bagi tenaga kesehatan sangat perlu disosialisasikan agar para tenaga kesehatan dalam menjalankann tugas dan tanggung jawab profesinya dapat merasa aman dan terlindungi oleh pemerintah dan peran serta pemerintah khususnya dinas yang terkait untuk memberikan pelatihanpelatihan tentang mitigasi bencana kepada para tenaga kesehatan yang bertugas di pelayanan perifer atau dilapangan.

\section{Kesimpulan}

Etik dan profesionalisme tenaga perawat dan bidan tentunya suatu tantangan tersendiri yang harus dipegang teguh didalam situasi bencana, tidak mudah untuk memilah untuk menolong korban yang berdatangan yang disaat bersamaan mengevakuasi pasien yang masih dalam tahap perawatan di PUSKESMAS Marawola, alat-alat dan prasarana medis yang terbatas dikarenakan akibat gempa beberapa fasilitas yang rusak, intimidasi dari keluarga korban, pengetahuan tentang peraturan dan mitgasi bencana, hingga kompetensi yang dimiliki sebagai tenaga perawat dan bidan, semuanya menjadi tantangan tersendiri dalam dilema untuk memutuskan tindakan apa yang harus diambil dengan segera.

Indonesia merupakan negara kepulauan yang dilalui oleh patahan lempeng bumi (ring of fire) yang artinya resiko bencana alam sangat besar sehingga dengan demikian diharapkan penelitian ini dapat berkesinambungan dan dikembangkan agar dapat diketahui lebih luas oleh pengambil kebijakan di negara ini hingga ke pelaksana kebijakan yang berada pada garda terdepan pada pelayanan kesehatan tingkat primer. 


\section{DAFTAR PUSTAKA}

1. Ardia,Ratna. Peran Dan Kepemimpinan Perawat Dalam Manajemen Bencana Pada Fase Tanggap Darurat.Sekolah Tinggi Ilmu Kesehatan Darussalam. Darul Islam, Sigli. 2015

2. Beuchamp TL, Childress JF. The Principle of Biomedical Ethics. Oxford University Press, New York. 2001

3. Darwin Eryati, Hardisman. Etika Profesi Kesehatan. Deepublish, Yogyakarta. 2014

4. Fatemeh, Karen. Ethical And Legal Challenges Associated With Disaster Nursing. Iran, Nursing Ethics. Sage, 2015,Vol.22, No.4. pp.493-503.

5. Ikatan Bidan Indonesia, Kode Etik Bidan Indonesia.2018

6. International Council of Nurses. ICN Framework of Competencies for the Nurse Specialist. Geneva, place Jean-Marteau, Switzerland. 2009

7. Jonsen AR, Siegler M, Winslade WJ. Clinical Ethics: a practical approach to ethical decisions in clinical medicine. McGraw-Hill, USA. 2002

8. Kementrian Kesehatan. Pedoman Pelaksanaan Paket Pelayanan Awal Minimum (PPAM) Kesehatan Reproduksi Remaja Pada Krisis Kesehatan 2017.Jakarta, 2018.

9. Kitab Undang-Undang Hukum Pidana (Wetboek Van Stafrecht) disahkan tahun 1918.

10. Kusmaryanto.Bioetika. Kompas, Jakarta. 2015.

11. Novria dkk.Faktor-faktor Yang Berhubungan Dengan Kesiapsagaan Bidan Dalam Menghadapi Bencana Gempa dan Tsunami Di PUSKESMAS Kota Padang, Padang. Jurnal Kesehatan, 2018. Vol.8, No.2.pp.338 - 345.

12. Persatuan Perawat Nasional Indonesia.Kode Etik Keperawatan Indonesia. 2015

13. Peraturan Menteri Kesehatan Republik Indonesia Nomor 26 Tahun 2019 Tentang Peraturan Pelaksanaan Undang-Undang Nomor 38 Tahun 2014 Tentang Keperawatan.
14. Peraturan Pemerintah Nomor 21 Tahun 2008 Tentang Penyelenggaraan Penanggulangan Bencana.

15. Peraturan Daerah Kabupaten Sigi Nomor 2 Tahun 2012 Tentang Penanggulangan Bencana Alam.

16. Sastrowijoto. THE BENEFIT OF ETHICS? WHO NEED ETHICS?, Bioetik,Sekolah Pasca UGM, Yogyakarta, 2014 (Slide Materi Ajar).

17. Sara. The Ethics of Disaster Management, Saudi Arabia, Disaster Prevention and Management :An International Journal, emerald insight. 2012 Vol. 21 Iss: 4 pp. $445-462$.

18. Sera Marcel, Setyowati Anna Maria Wahyu .Dilema Etik Dan Hukum Dalam Pelayanan Medis. Mandar Maju, Bandung, 2010.

19. Siswanto Sastrohadiwiryo. Manajemen Tenaga Kerja Indonesia Pendekatan Administratif dan Operasional. Bumi Aksara, Jakarta,2002.

20. Syamsiyatun, Siti Wafiroh Nihayatul. Filsafat, Etika dan Kearifan Lokal Untuk Kosntruksi Moral kebangsaan. Globalethics ,Jenewa. 2013.

21. Sukmawati. Kearifan Lokal Masyarakat Kaili di Sulawesi Tengah.Untad, Palu, 2013.

22. Triwibowo. Etika Dan Hukum Kesehatan. Nuha Medika, Yogyakarta. 2014.

23. Undang-Undang Dasar Negara Republik Indonesia tahun 1945.

24. Undang-Undang Republik Indonesia Nomor 30 Tahun 2014 Tentang Administrasi Pemerintahan.

25. Undang-Undang Republik Indonesia Nomor.36 Tahun 2009 Tentang Kesehatan

26. Undang-Undang Republik Indonesia Nomor 36 Tahun 2014 Tentang Tenaga Kesehatan.

27. Undang-Undang Nomor 38 Tahun 2014 Tentang Keperawatan.

28. Undang-Undang Republik Indonesia Nomor 4 Tahun 2019 Tentang Kebidanan. 